УДК 94 (477): 355.133.4+082 “УНР” 1917/1918 (929)

DOI: $10.33099 / 2707-1383-2021-41-3-60-73$

\author{
Ярослав Стеців \\ ад 'юнкт штатний науково-організаиійного \\ відділу, \\ Наиіональна академія сухопутних військ \\ імені гетьмана Петра Сагайдачного \\ (Львів, Україна) \\ ORCID: https://orcid.org/0000-0003-4754-7452 \\ Електронна пошта: stetsiv@uси.edu.иа
}

\title{
СУСПІЛЬНО-ПОЛІТИЧНІ НАСТРОЇ ОФІЦЕРІВ-АРТИЛЕРИСТІВ НА ТЛІ РЕВОЛЮЦІЙНИХ ПОДІЙ В УКРАЇНІ В ПЕРІОД 1917-1918 pр.
}

У статті висвітлені особливості суспільно-політичних настроїв офічерів-артилеристів украӥнського війська на тлі револючійних подій в Украйні в період 1917-1918 рр. Особливу увагу присвячено прочесу трансформачї свідомості офічерів та конструювання образу влади на тлі револючійних, воєнно-політичних та сочіально-економічних подій в Україні niд час зазначеного періоду. Наведено ключові аспекти взаємовідносин та причини конфронтачії між владою та офічерським корпусом.

Ключові слова. Українська револючія 1917-1921 рр., офіцерський корпус, Центральна Рада, суспільно-політичні настрої, артилерія.

Постановка проблеми. Проблема суспільно-політичних настроїв офіцерів-артилеристів та їхніх взаємовідносин із політиками Центральної Ради має важливе значення для вивчення військової історії періоду Української революції 1917-1921 pp.

Як відомо, основу будь-якої армії становлять офіцери. Відомий український історик М. Литвин зауважив: «...жодна армія, незалежно від рівня озброєння $і$ вишколу, не може перемагати без досвідчених воєначальників. Їі лице завжди визна- чають генералітет $i$ офіиерський корпус - становий хребет війська» (Литвин, М. Р. \& Науменко, К. Є. 2007, c. 3).

Серед командного складу українського війська періоду Центральної Ради провідна роль належить офіцерам-артилеристам, адже артилерія на той час була одним із найбільш боєздатних родів зброї. Подальший розвиток подій Визвольного руху засвідчує значимість гармашів у боях із противниками української державності (бої за Львів у листо- 
паді 1918 р., Чортківська офензива в червні 1919 р., бій за Вапнярку в липні 1919 р., похід на Київ в серпні 1919 р., та ін.) (Шанковський, Л. П. 1958 , c. 45 ).

Під час Першої світової війни артилерія закріпила за собою статус провідного роду зброї, отримала потужний імпульс для розвитку, а іiі командні кадри проявили себе якнайкраще. Значного бойового досвіду набули й українські офіцери-артилеристи, які становили кістяк гарматних батарей та дивізіонів російської армій (Внуков, В. П. 1937, 74 с.).

Офіцерський корпус артилерії відігравав важливу роль й у битвах українських армій. Одразу ж після повернення 3 фронту офіцери-артилеристи, усвідомлюючи значимість артилерії для війська, взялися формувати гарматні батареї та дивізіони. Великий вплив на ефективність офіцерів мали їхні суспільно-політичні орієнтири та взаємовідносини i3 владою, адже стратегічні завдання війську визначають політичні лідери.

Проте погляди української політичної еліти щодо використання військового потенціалу колишньої російської армії відрізнялися від намірів офіцерського корпусу формувати повноцінне військо з усіма родами зброї, включно з артилерією. Більшість урядовців симпатизували ідеї створення «всенародної міліції» як альтернатива регулярній армії (Зінкевич, Р. Д. 2014, с. 113).
Ворожа пропагандистська агітація (більшовиків та учасників білого руху Росіі), суперечливі політичні рішення Центральної Ради (декрет про демобілізацію української армії від 17.01.1918 р. тощо) посилювали взаємну недовіру та негативно вплинули на конструювання суспільно-політичних поглядів офіцерського корпусу (Дашкевич, Р. I. 1965, с. 10; Шанковський, Л. П. 1958, с. 9).

Наростаючі протиріччя та погіршення стосунків урядовців 3 офіцерами дуже часто ставали на заваді ефективному будівництву війська i сприяли загарбницьким планам ворогів України. Зазначені обставини в подальшому мали фатальні наслідки для існування молодої української держави.

Аналіз останніх досліджень і публікацій. В українській історіографії пропонована тема ще не була грунтовно досліджена. В окремих публікаціях частково відображено процес конструювання образу влади у свідомості офіцерів (Тютенко, Р. В. 2017а, с. 142-153), проаналізовано суспільно-політичні настрої та розглянуто особливості трансформації політичних переконань офіцерського складу Дієвої армії УНР і Галицької Армії (Тютенко, Р. В. 2017b, с. 111-114; Тютенко, Р. В. 2017c, с. 60-68). Складові визначеної проблеми знайшли певне відображення в роботах В. Верстюка (Верстюк, В. Ф 2007), В. Голубка (Голубко, В. Є. 1997, 
275 с.) та П. Голуба (Голуб, І. П. 1958, 254 c.).

Проте питанням суспільно-політичних настроїв офіцерів-артилеристів на тлі революційних подій в Україні в період 1917-1918 рр. наукових публікацій досі не присвячено. Основним джерелом є спогади військових і громадсько-політичних діячів доби УНР, зокрема В. Винниченка, М. Грушевського, Р. Дашкевича, Є. Коновальця, К. Смовського, В. Савченка та інших.

Розбіжності у їхніх політичних поглядах вплинули не лише на свідомість офіцерів, але й на боєздатність українського війська загалом.

Мета дослідження. На основі спогадів військових та громадсько-політичних діячів проаналізувати суспільно-політичні настрої офіцерів-артилеристів українського війська на тлі революційних подій в Україні в період 1917-1918 pp.

Виклад основного матеріалу дослідження. Унаслідок Першої світової війни $з$ політичної карти світу зникли дві імперії: Російська та Австро-Угорська. Поневолені народи, які перебували в складі монархій, отримали можливість збудувати незалежні держави. Українці займали важливе місце серед народів колишніх імперій, адже переважали інших кількісно та були одночасно репрезентовані як у Російській, так і в Австро-Угорській монархії.

Отримавши звістку про повалення влади царя в Петрограді в березні-лю- тому 1917 р., на українських землях активізувався визвольний рух, який мав на меті здобути державність. Серед найактивніших представників суспільства, котрі одними із перших приєдналися до Визвольних змагань, були українські офіцери. Третину від загальної кількості офіцерського корпусу, який вступив до лав українських військових формацій, були офіцери-артилеристи. Варто зазначити, що відомі учасники тих подій відзначали високу професійність офіцерів-гармашів. Л. Шанковський писав: «... мали добрих, досвідчених артилерійських старшин $і$ справних гармашів. До самого кіния Визвольних змагань вона (артилерія) була надійним бойовим родом зброї, щчо часто вирішував вислід окремих боїв» (Шанковський, Л. П. 1958, с. 45).

Офіцери, як особлива соціальна група, завжди були кістяком регулярного війська, адже становили найефективнішу частину кадрів будь-яких збройних сил (Лозинський, А. Ф. 2017 , с. 47).

Проте російська революційна хвиля, яка після Першої світової війни охопила території колишньої Російської імперії, не оминула і військо та дуже негативно вплинула на нього. Українці в царській армії були представлені значною кількістю офіцерів та солдат. За даними історика Я. Тинченка, в російській армії офіцери українського походження становили близько $-20 \%$ або 70 тис. осіб. Загальна ж кількість українців, які були 
мобілізовані в період 1914-1918 рр., становила близько - 1,8 млн. осіб (Тинченко, Я. Ю. 2011, с 49).

Значна кількість українців, які перебували на фронтах, щиро підтримували Визвольний рух. Про це свідчать дані історика Л. Шанковського, який подає статистичні показники політичних настроїв українських вояків, які проголосували «за списки самостійницьких украӥнських партій», опубліковані під час Установчих зборів в грудні 1917 р. Зокрема: Північний фронт — 88956 голосів; Західний фронт — 85 062; Південно-Західний фронт - 168 354; Румунський фронт - 180 576; Чорноморська Фльота — 12 895; всього — 535843 голоси (Шанковський, Л. П. 1958, с. 23).

Уже в лютому-березні 1917 p. в російській армії з ініціативи офіцерів розпочато стихійний рух зі створення перших українських ротних громад, корпусних рад та армійських комітетів, ряди яких щоденно поповнювались новими учасниками (Химиця, Н. О. 2009, с. 25).

Проте наслідки затяжної світової війни призвели до деморалізації армії, що негативно вплинуло на настрої офіцерів. Серед фронтових частин почастішали випадки дезертирства, які набували масового характеру. Як зазначалося в рапорті генерала М. Алексеєва до військового міністра О. Гучкова: «... в арміях Південно-Західного $і$ Румунського фронтів тільки з передових позицій за той же час (1-7 квітня 1917 р.) дезертирувало 347 вояків» (Тютенко, Р. В. 2017с, с. 112).

Щоденно знижувався рівень дисципліни, а порушники військових обов'язків ставилися байдуже до покарання. Тому падав рівень авторитету офіцерів серед рядових, які розпочали створювати солдатські комітети та вимагали усунення командирів від управління армійськими підрозділами. Через політизованість війська та активну пропаганду в офіцерському середовищі щодня падав бойовий дух, а серед солдат наростала протестна хвиля, яку неможливо було вже зупинити (Базанов, С. Н. 2010, c. 43).

Найбільше під негативний вплив анархії підпадали російські офіцери, швидко втрачаючи мотивацію до служби. Українське офіцерство виявилося більш стійким, тому відбулося їхнє певне дистанціювання від росіян. В. Савченко описував: «B изей час не тільки украӥнець-старшина, а навіть звичайний солдат, дивився з презирством на свойх московських товаришів» (Садовський, М. В. (ред.). 1935, с. 54).

Проте український військовий рух міг запросто розвалитися, адже не всі офіцери були готові доєднатися до демократичних державотворчих процесів. Учасники тих подій зауважували, що існувала певна група командирів вищих рангів, які були переконані в неспроможності навести порядок будь-якою вла- 
дою, окрім «батюшки-иаря» (Галаган, М. М. 2005, с. 193-194).

Після оголошення Центральною Радою (далі ЦР) відозви «До українського народу», якою закликали інтелігенцію, робітників та військових зберігати спокій, об'єднуватися в культурні, політичні та економічні союзи, українські офіцери, зокрема артилеристи, були одними 3 перших, хто відгукнувся на звернення влади. В той день відбулися збори офіцерів та солдатів Київської міської залоги, на яких утворили Установчу українську військову раду під керівництвом М. Глинського. Під час зборів було прийнято ряд документів, серед яких найважливішим стало звернення до Тимчасового уряду: «... вчинить для Украӥни ще до скликання Установчих зборів такий самий правний акт, який вже видано для Фінляндії $i$ потвердить за Українським народом всі права і вільності» (Верстюк, В. Ф. 2007).

Однак не всі офіцери одразу визнали легітимність ЦР. В березні 1917 р. з'явилася група офіцерів, які утворили в Києві Всеросійський військовий союз, який у своєму заклику до вояків на початку квітня 1917 р. декларував: «Тимчасовий уряд $\epsilon$, до скликання Установчих зборів, єдиним правоздатним $i$ відповідальним виконавцем волі Росії» (Тютенко, Р. В. 2018, c. 102).

Та все ж переважна більшість офіцерського корпусу публічно визнали український уряд. Уже під час мані- фестацій українських офіцерів (в березні-квітні 1917 р. у Києві) можна простежити їхнє ставлення до уряду. 25 березня на Хрещатику було проведено збори військових частин різних родів зброї, де офіцери привітали гучними оплесками та підтримали М. Грушевського. Газета «Нова Рада» писала: «Настрій росте й шириться на юрбу, досягає найбільшої сили, коли підходить скромна валка, на чолі якої професор М. Грушевський ... 3 юрби летять вигуки до балкону: покажіть нам його! Покажіть нам Грушевського! ... Двоє офіџерів підхоплюють М. Грушевського на руки $i$ несуть на гору на балкон. Члени військового Комітету розступаються і оплесками зустрічають славного украӥния. Перед М. Грушевським величезна привітна юрба ... Місто Київ вітає його, як представника українського руху ...» (Тютенко, Р. В. 2018 , с. 102-103).

Українські офіцери та солдати визнавали ЦР як єдиний представницький орган українського народу. Свідченням їхньої відданості були вітальні листи, які весною 1917 p. надходили із різних військових частин та фронту. Вояки Бессарабського полку надіслали вітання із текстом: «... од щирого серия $i$ глибини душі вітаю Українську Центральну Раду, бажаю успіху ...». Вояцтво 247го полку з м. Новоузенська надіслали лист М. Грушевському, в якому йшлося про визнання влади ЦР: «nрuвітать рідну Україну в лиці Вас, як 
придсідателя Центральної Ради»

(Тютенко, Р. В. 2018, с. 103).

Очевидно, що інтереси українського офіцерства цілком збігалися 3 інтересами ЦР, адже обидві сторони мали за кінцеву мету здобуття суб'єктності України.

Стосунки погіршилися після антимілітаристських заяв М. Грушевського та В. Винниченка, які не вбачали у війську реальної військової сили, здатної стати опорою ЦР, і лише рішучість українських офіцерів змусила уряд організувати військові з'їзди (Матяшук, В. П. 2007, с. 108).

Голова Генерального Секретаріату В. Винниченко заявляв: «Не своєї армії нам, соиіал-демократам, треба, а знищення всяких постійних армій». Схожою була позиція М. Грушевського, який у праці «На порозі нової України» писав: «Нормальною формою охорони для демократичної держави являсться всенародна мілічія» (Тютенко, Р. В. 2018, с. 105).

Тому закономірним $\epsilon$ i той факт, що будівництвом українського війська опікувалися здебільшого не керівники ЦР, а офіцерський корпус (Фурман, I. I. \& Печенюк, I. С. 2020, с. 63).

Під тиском зовнішніх воєнно-політичних обставин (наступ більшовицьких військ) у подальшому урядовці все ж таки пішли на певні поступки військовим та розпочали кроки зі створення власної армії. Було утворено військову комісію для координації дій українського військового руху та призначено на 5 травня
1917 р. скликання Першого Всеукраїнського військового з'їзду, під час якого делегати публічно підтримали ЦР (Тютенко, Р. В. 2017b, с. 106).

Перший Всеукраїнський військовий з'їзд дав поштовх для формування різноманітних об'єднань офіцерів за родами зброї. Зокрема, 11 травня 1917 р. на з'їзді українців-артилеристів Запасної армії в Казані утворено Український військовий комітет, який очолив полковник Савченко. Під час з’їду прийнято резолюцію про формування українських гарматних частин та утворено військову делегацію, яку направили до Києва. Значно далі просунувся з'їзд українців-артилеристів Північного фронту, під час якого 642 учасники утворили Раду гарматників Сухопутного фронту та виступили зі зверненням до Командування артилерії і Головного артилерійського управління російської армії з принциповою вимогою утворити українські гарматні формації на всіх фронтах Російської імперії (Ткачук, П. П. 2009, с. 133).

Із числа фронтових частин російської армії найбільшу проукраїнську активність влітку 1917 р. проявляли гармаші Південно-Західного фронту. Вже під час Другого Всеукраїнського військового з'їзду зазначалося, що до 18 червня 1917 р. українізовано 17 піхотних дивізій, а в їх складі 17 легких гарматних бригад - 102 батареї, які мали 612 гармат.

Із квітня 1917 р. розпочато процес українізації військових навчальних 
закладів артилерії, які дислокувались на Наддніпрянщині. Наприкінці квітня 1917 р. в Києві утворено Всеукраїнську юнкерську спілку, яка об'єднала 32 навчальні заклади артилерії. Спілка ухвалила на своєму з'їзді 16 липня 1917 р. резолюцію, в якій вимагала від Українського військового генерального комітету «негайно i найрішучіше взятися за формування украӥнських частин», та направляти українців виключно на посади в українське військо (Ткачук, П. П. 2009, с. 133-134).

Активна українізація артилерії частково пояснювалась ऑiі віддаленим розміщенням від лінії фронту Першої світової війни. Однак більш значний вплив на темпи реорганізації імперської армії та перехід вояцтва на службу українському народу мала патріотична свідомість офіцерів-артилеристів, які становили кістяк гарматних частин. Подекуди гармаші були більш ефективні за своїх колеги 3 інших родів зброї. Л. Шанковський відзначав: «Дуже часто українська артилерія випереджала піхоту в наступі, засипаючи супротивника картечним вогнем зі своїх гармат, а у відвороті часто відступала останньою, стримуючи надто вже сильний натиск ворога» (Шанковський, Л. П. 1958, с. 45).

Українські артилеристи, як і їхні товариші з інших родів зброї, бажали стати опорою для українського уряду. Ось так згадував досвідчений артилерист, генерал-хорунжий Р. Даш- кевич про полонених офіцерів, які пізніше утворили перший український гарматний підрозділ: «Революиія збудила в ичих людей надію на волю. Багато ичих полонених украӥнців старалося дістатися на Україну, звідки приходили вістки про Українську Центральну Раду, універсали УЦР, військові з'їзди, українське військо. Дістатися на Украӥну, там стати до праиі, ... помогти в будові украйнської держави, затягнутися до украӥнського війська, - ие було їхньою мрією» (Дашкевич, Р. I. 1965, c. 5).

Великий вплив на формування проукраїнських суспільно-політичних поглядів офіцерів-артилеристів мала доба Козаччини та творчість Тараса Шевченка. «Козаиька доба будила в нас думки, що козаки на Дніпрових порогах не були “русскими”, щуо Шевченко, який у своїх віршах оспівував козаџькі славні героїчні походи, не був “русским”, ні “малорусским писателем”, а українським”», - згадував сотник А. Дідковський (Дідковський, А. Г. 1961, с. 27).

Попри певне позитивне просування у взаємовідносинах урядовці ЦР не поспішали довіряти офіцерському корпусу. 3 одного боку, недовіра уряду до кадрових командирів була пов'язана 3 побоюванням, що офіцери, які виховані в дусі «єдіной, недєлімой, монархіческой Россії», в критичний момент не підтримають українську владу. А 3 іншого боку, як згадував генерал-хорунжий 
М. Капустянський, що після Лютневої революції 1917 р. «з'явилася сила авантурників, часто повних анальфабетів у військових справах, людей без жадної моральної сталости, частенько і не старшин» (Капустянський, М. О. 2004, с. 40).

Ставлення лідерів ЦР до офіцерів змінилося після більшовицького перевороту в листопаді 1917 p. Вже почали формуватися регулярні військові частини: Гайдамацький Кіш Слобідської України та Галицько-Буковинський курінь Січових Стрільців (Ткачук, П. П. 2009, с. 136).

Змінилася й позиція М. Грушевського, який зазначав: «Нам на якийсь час буде доконче потрібна хоч невелика, але добра, тверда, дисииплінована армія» (Гончар, О. Т. (ред.) \& Демиденко, А. П. (упоряд.) 1992, c. 172-173).

За дорученням інспектора артилерії полковника Афанасієва в листопаді 1917 р. К. Смовський утворив гарматну батарею Гайдамацького кошу Слобідської України. Він зауважував, що на початку Першої українськобільшовицької війни українізовані гарматні частини розвалювалися або разом із піхотними переходили до ворога, тоді як заново створені українські артилерійські формації зберігали свою боєздатність (Ткачук, П. П. 2009, c. 137).

Тоді ж Р. Дашкевич сформував гарматну батарею у складі Галицько-Буковинського куреня (Ткачук, П. П. 2009, с. 136). Як пізніше згадував про батарею відомий командир Січових Стрільців - С. Коновалець: «... neревірив перегляд усіх частин Січових Стрільців ... признав, щзо в артилерії був таки найкращий порядок» (Дашкевич, Р. I. 1965, с. 126).

У той самий час у Києві О. Алмазов утворив кінно-гарматний дивізіон, який згодом був одним iз найбільш боєздатних частин українських військ та іменувався «Алмазівським». У подальшому зазначені батареї і дивізіони виявилися найбільш життєздатними й, по суті, єдиними, на кого опиралася українська влада в перших боях за державність (Ткачук, П. П. 2009, с. 136).

Нерішучість ЦР дуже дратувала українських офіцерів, які вимагали від влади чіткого плану дій. Як згадував полковник М. Чеботарів: «Tym ведуться бої в суміжних вулииях, в Украӥнській Центральній Раді, чи Генеральному Секретаріяті відбуваються чергові засідання, власне, балаканина нікому не потрібна, бо в цей час вже не розмовляти треба, а брати в руки рушниці і битися ...». Лише після захоплення більшовиками влади в Києві, уряд, усвідомлюючи трагічність ситуації, кардинально змінив свою політику та дозволив офіцерам формувати регулярне військо. Та все ж було згаяно багато часу і можливостей, лідери ЦР остаточно втратили довіру серед офіцерів командирі, а політичну владу внаслідок перевороту захопив П. Скоропадський (Тютенко, Р. В. 2018, с. 107). 
Висновки. Отже, наприкінці Першої світової війни, події розгорталися несприятливо для російської армії, тому офіцерський корпус відчував неминучі зміни.

Новину про зречення імператора Миколи II та падіння самодержавства в Російській імперії, українські офіцери, зокрема артилеристи, сприйняли здебільшого спокійно, тоді як російські зазнавали впливу анархії, яку спричинила революційна хвиля у війську та по всій країні.

В наслідок Лютневої революції 1917 р., російська армія була деморалізована та перебувала в стані розпаду, а офіцери, котрі втрачали владу, постали перед дилемою політичного вибору: підтримати Центральну Раду, чи залишитись в підпорядкуванні Тимчасового уряду Росії.

Український офіцерський корпус поділився на дві категорії. Переважну більшість склали не кадрові офіцери, котрі заявили про підтримку демократичного ладу та формування нових українських державних інституцій.

Друга категорія - кадрові офіцери, які сформували опозицію до нових порядків у війську, сприймаючи зміни, в першу чергу, як пониження власного соціального статусу.

Перемогла продемократична течія, яка підтримувала розпад імперії та утворення української держави. Вони заявляли про тверді наміри фомувати військо для захисту українських земель від зовнішніх ворогів.

Неабиякий вплив на свідомість офіцерів-артилеристів мала культурна та історична спадщина українського народу (творчість Т. Шевченка, Козаччина), яка руйнувала усталену систему цінностей та переконань меншовартості українців, їхнього поступового переходу від парадигми «офіцери-малороси» до самоусвідомлення «офіцериукраїнці».

Однак, непослідовна політика ЦР щодо питань війська, сприяла формуванню недовіри офіцерів до українських політичних лідерів та сповільнювала будівничі процеси у війську.

Та все ж, загалом, політичні погляди офіцерського корпусу і лідерів ЦР збігалися. Більшість офіцерів бачили майбутній державний устрій України, як автономну одиницю федеративної республіки колишньої Російської імперії.

\section{СПИСОК ВИКОРИСТАНИХ ДЖЕРЕЛ І ЛІТЕРАТУРИ}

Базанов, С. Н. (2010). Антивоенное выступление на русском фронте в (1917 г.) глазами современников (воспоминание, документы, комментарии). Москва, 363 с.

Верстюк, В. Ф. (2007). Українська Центральна Рада і армія. Воєнна історія. № 1-3 (31-33). Київ, 2007 рік. URL: http://warhistory.ukrlife.org/1_3_07_2.htm [дата зверн.: 24.06.2021].

Внуков, В. П. (1937). Артилерія. Київ, 74 с. 
Голубко, В. С. (1997). Армія Української Народної Республіки (1917-1918). Утворення та боротьба за державу. Львів: Кальварія, 275 с.

Голуб, І. П. (1958). Солдатские массы Юго-Западного фронта в борьбе за власть Советов (март 1917 г. - февраль 1918 г.). Киев: Госполитиздат УССР, 254 с.

Гончар, О. Т. (ред.). \& Демиденко, А. П. (упоряд.). (1992). Великий украӥнець. Матеріали з життя та діяльності М. Грушевського. Київ, 552 с.

Галаган, М. М. (2005). 3 моїх споминів. (1880-mi - 1920 р.): Документально-художнє видання. Київ: Темпора, 656 с.

Дашкевич, Р. І. (1965). Артилерія Січових Стрільців у боротьбі за Золоті київські вороma. Нью-Йорк: Червона Калина, 205 с.

Дідковський, А. Г. (1961). Спогади. Новий Ульм: Українські вісті, 83 с.

Зінкевич, Р. Д. (2014). Початки формування армії УНР (восени 1917 року). Вісник Наџіонального університету «Львівська політехніка». № 784: (Держава та армія), с. 107-113.

Капустянський, М. О. (2004). «Похід армій на Київ-Одесу. В 1919 роиі». Київ: Темпора, $558 \mathrm{c}$.

Литвин, М. Р. \& Науменко, К. Є. (2007). Збройні сили Украӥни першої половини ХХ ст. Генерали та адмірали. Львів; Харків: Сага, 244 с.

Лозинський, А. Ф. (2017). Українці в системі кадрового забезпечення Сухопутних військ Збройних сил Російської імперії (наприкінці XIX-початку XX ст.). Військово-науковий вісник. № 27, с. 46-70. DOI: https://doi.org/10.33577/2313-5603.27.2017.46-70.

Матяшук, В. П. (2007). Помилки військової політики М. Грушевського як Голови Центральної Ради. Держава та армія: видавництво Національного університету «Львівська політехніка». с. 107-112.

Садовський, М. В. (ред.). (1935). Спогади про украӥнський рух у ХІІ російській армії y (1917 р.). За державність. Матеріали до історії війська українського (в 11 т., Т. 1). Каліш: Воєнно-історичне товариство, 212 с.

Тинченко, Я. Ю. (2011). Офіцерський корпус армії Украӥнської Народної Республіки (1917-1921). Київ: Темпора, 424 с.

Ткачук, П. П. (2009). Сухопутні війська Збройних Сил Украӥни доби революиії (19171921 рр.): дис. док. іст. наук: 07.00.01 - Історія України. Львів, 311 с.

Тютенко, Р. В. (2017а). Політичні настрої і конструювання образу влади УНР та ЗУНР у сприйнятті українських офіцерів (1918-1920рр.). Військово-науковий вісник. № 28, c. $142-153$.

Тютенко, Р. В. (2017b). Офіцери і суспільно-політичні виклики на тлі революційних процесів в Україні в (1917р.). Наукові прачі історичного факультету Запорізького національного університету. № 48, с. 111-114.

Тютенко, Р. В. (2017c). Поняття війни «за Україну» у свідомості офіцерів Дієвої армії УНР та УГА (1918-1921). Україна: культурна спадщинна, національна свідомість, державність. № 30 , c. $60-68$. 
Тютенко, Р.В. (2018). Соціальний портрет офіцера украӥнських армій періоду Національної революиії (1917-1921 рр.): дис. канд. іст. наук: 07.00.01 — Історія України. Львів, 246 с.

Фурман, I. I. \& Печенюк, I. С. (2020). Перший Всеукраїнський військовий з'їзд та його значення в національному державотворенні й українізації армії. Військово-науковий вісник. № 33, c. 61-74. DOI: https://doi.org/10.33577/2313-5603.33.2020.61-74.

Химиця, Н. О. (2009). Український національний рух у російській армії та участь у ньому молоді (весна-літо 1917 р.). Проблема гуманітарних наук: збірник наукових праиь ДдПУ імені I. Франка. Серія Історія. № 24, с. 23-37. DOI: https://doi.org/10.24919/2312-2595.24.172160.

Шанковський, Л. П. (1958). Украӥнська армія в боротьбі за державність. Мюнхен: Дніпрова хвиля, 317 с.

\section{REFERENCES}

Bazanov, S. N. (2010). Antivoennie vistuplenie na russkom fronte v (1917 g.) glazami sovremennikov (vospominanie, dokumenti, komentarii) [Anti-war speech on the Russian frontline in 1917 from the contemporaries' prospective (memoirs, documents, comments)]. Moskva, 363 s. [in Russian].

Verstiuk, V. (2007). Ukrainska Tsentralna Rada i armiiav [Ukrainian Central Rada and Armed Forces.] Voienna istoriia. № 1-3 (31-33). Kyiv, 2007 rik. URL: http://warhistory.ukrlife. org/1_3_07_2.htm [Accessed: 24.06.2021]. [in Ukrainian].

Vnukov, V. P. (1937). Artyleriia [Artillery]. Kyiv, 74 s. [in Russian].

Holubko, V. Ie. (1997). Armiia Ukrainskoi Narodnoi Respubliky (1917-1918). Utvorennia ta borotba za derzhavu [Army of the Ukrainian People's Republic 1917-1918. Establishment and struggle for the statehood]. Lviv: Kalvariia, 275 s. [in Ukrainian].

Golub, I. P. (1958). Soldatskie massi Yugo-Zapadnogo fronta v borbe za vlast Sovetov (mart 1917 g. - fevral 1918 g.) [Soldiers' strength of the South-Western Front in the struggle for Soviet power (March 1917 - February 1918)]. Kiev: Gospolitizdat USSR, 254 c. [in Ukrainian].

Honchar, O. T. (red.). \& Demydenko, A. P. (uporiad.). (1992). Velykyi ukrainets. Materialy z zhyttia ta diialnosti M. Hrushevskoho [The great Ukrainian. Materials on the life and activity of M. Hrushevsky]. Kyiv, 552 s. [in Ukrainian].

Galagan, M. M. (2005). Z moikh spomyniv. (1880-ti-1920 r.): Dokumentalno-khudozhnie vydannia [From my memories. (1880-1920): Documentary and fiction edition]. Kyiv: Tempora, 656 s. [in Ukrainian].

Dashkevych, R. I. (1965). Artyleriia Sichovykh Striltsiv u borotbi za Zoloti kyivski vorota [Artillery of Sich Riflemen in the fight for the Golden Gate of Kiev]. Niu-York: Chervona Kalyna, 205 s. [in Ukrainian].

Didkovskyi, A. H. (1961). Spohady [Memoirs]. Novyi Ulm: Ukrainski visti, 83 s. [in Ukrainian]. 
Zinkevych, R. D. (2014). Pochatky formuvannia armii UNR (voseny 1917 roku) [The initiation of the UPR army in the autumn of 1917]. Visnyk Natsionalnoho universytetu "Lvivska politekhnika”. № 784: (Derzhava ta armiia), s. 107-113. [in Ukrainian].

Kapustianskyi, M. O. (2004). "Pokhid armii na Kyiv — Odesu. V 1919 rotsi” [“Army march on Kyiv-Odessa. In 1919”]. Kyiv: Tempora, 558 s. [in Ukrainian].

Lytvyn, M. R. \& Naumenko, K. Ie. (2007). Zbroini syly Ukrainy pershoi polovyny XX-st. Heneraly ta admiraly [The Armed Forces of Ukraine in the first half of the XX-th century. Generals and admirals]. Lviv; Kharkiv: Saha, 244 s. [in Ukrainian].

Lozynskyi, A. F. (2017). Ukraintsi v systemi kadrovoho zabezpechennia Sukhoputnykh viisk Zbroinykh syl Rosiiskoi imperii (naprykintsi XIX — pochatku XX st.) [Ukrainians in the human resources system of the Land Forces of the Armed Forces of the Russian Empire (in the late XIXth — early XXth centuries)]. Viiskovo-naukovyi visnyk. № 27, s. 46-70. DOI: https://doi. org/10.33577/2313-5603.27.2017.46-70. [in Ukrainian].

Matiashuk, V. P. (2007). Pomylky viy̆skovoï polityky M. Hrushevskoho yak Holovy Tsentralnoï Rady [Mistakes in the military policy of M. Hrushevsky as Chairman of the Central Rada]. Derzhava ta armiia: vydavnytstvo Natsionalnoho universytetu "Lvivska politekhnika", s. 107-112. [in Ukrainian].

Sadovskyi, M. V. (red.). (1935). Spohady pro ukrainskyi rukh u XII rosiiskii armii u (1917 r.) [Memoirs of the Ukrainian movement in the XII Russian army in 1917]. Za derzhavnist. Materiialy do istorii viiska ukrainskoho (v 11 t., T.1). Kalish: Voienno-istorychne tovarystvo, 212 s. [in Ukrainian].

Tynchenko, Ya. Iu. (2011). Ofitserskyi korpus armii Ukrainskoi Narodnoi Respubliky (19171921) [Officer Corps of the Army of the Ukrainian People's Republic (1917-1921)]. Kyiv: Tempora, 424 s. [in Ukrainian].

Tkachuk, P. P. (2009). Sukhoputni viyška Zbroynykh Syl Ukraïny doby revoliutsiï (1917$1921 \mathrm{rr}$.) [Land forces of the Armed Forces of Ukraine during the Revolution (1917-1921)]. (Doctore's thesis). Lviv, 311 s. [in Ukrainian].

Tiutenko, R. V. (2017a). Politychni nastroi i konstruiuvannia obrazu vlady UNR ta ZUNR u spryiniatti ukrainskykh ofitseriv (1918-1920 rr.) [Political attitudes and the image establishment of the leadership in the Ukrainian People's Republic and the Western Ukrainian People's Republic in the perception of Ukrainian officers (1918-1920)]. Viiskovo-naukovyi visnyk. № 28, s. 142-153. [in Ukrainian].

Tiutenko, R. V. (2017b). Ofitsery i suspilno-politychni vyklyky na tli revoliutsiinykh protsesiv v Ukraini v (1917 r.) [Officers, social and political challenges on the background of revolutionary processes in Ukraine (in 1917)]. Naukovi pratsi istorychnoho fakultetu Zaporizkoho natsionalnoho universytetu. № 48, s. 111-114. [in Ukrainian].

Tiutenko, R. V. (2017c). Poniattia viiny “za Ukrainu” u svidomosti ofitseriv Diievoi armii UNR ta UHA (1918-1921) [The concept of war "for Ukraine" in the minds of officers of the Regular Army 
of the Ukrainian People's Republic and the Ukrainian Halychyna Republic (1918-1921)]. Ukraina: kulturna spadshchyna, natsionalna svidomist, derzhavnist. № 30, s. 60-68. [in Ukrainian].

Tiutenko, R. V. (2018). Sotsialnyi portret ofitsera ukrainskykh armii periodu Natsionalnoi revoliutsii (1917-1921 rr.) [Social portrait of an officer of the Ukrainian armies in the period of the National Revolution (1917-1921)]. (Candidate's thesis). Lviv, 246 s. [in Ukrainian].

Furman, I. I. \& Pecheniuk, I. S. (2020). Pershyi Vseukrainskyi viiskovyi zizd ta yoho znachennia v natsionalnomu derzhavotvorenni y ukrainizatsii armii [The First All-Ukrainian Military Congress and its significance in the nation-building and Ukrainization of the army]. Viiskovo-naukovyi visnyk. № 33, s. 61-74. DOI: https://doi.org/10.33577/2313-5603.33.2020.61-74. [in Ukrainian].

Khymytsia, N. O. (2009). Ukrainskyi natsionalnyi rukh u rosiiskii armii ta uchast u nomu molodi (vesna - lito 1917 r.) [Ukrainian national movement in the Russian army and youth participation (spring — summer 1917)]. Problema humanitarnykh nauk: zbirnyk naukovykh prats DDPU imeni I. Franka. Seriia Istoriia. № 24, s. 23-37. DOI: https://doi.org/10.24919/2312-2595.24.172160. [in Ukrainian].

Shankovskyi, L. P. (1958). Ukrainska armiia v borotbi za derzhavnist [Ukrainian army in the struggle for the statehood]. Miunkhen: Dniprova khvylia, 317 s. [in Ukrainian].

\section{Yaroslav Stetsiv}

postgraduate of graduate school of Hetman

Petro Sahaidachnyi National Academy of

Ground Forces (Lviv, Ukraine)

ORCID: https://orcid.org/0000-0003-4754-7452

\section{SOCIAL AND POLITICAL ATTITUDES OF ARTILLERY OFFICERS ON THE BACKGROUND OF REVOLUTIONARY EVENTS IN UKRAINE THROUGHOUT 1917-1918 YEARS}

Research objective: to analyze the social and political attitudes of the artillery officers of the Ukrainian army on the background of the revolutionary processes in Ukraine throughout 1917-1918 years.

The research methodology is based on the principles of historicism, objectivity including methods of analysis, synthesis, generalization and information.

Scientific novelty lies in the fact that, despite the range of Ukrainian historiography individual studies on the officer corps, to date not the social and political views of the artillery officers haven't been comprehensively analyzed on the backdrop of revolutionary events in Ukraine during 1917-1918 so far. Set up on archival sources, official and unofficial documents as well as memoirs of actual participants, the relationship between political 
leaders and the Central Council of the officer corps, which had an impact not only on the development of political preferences of the Ukrainian artillery officers, but also to combat capability of Ukrainian army in the whole has been studied.

Conclusions. Unfavorable consequences for the Russian army of the First World War negatively affected the officer corps, who anticipated imminent change. Ukrainian officers, including artillerymen, calmly accepted the collapse of the autocracy in the Russian Empire, while the Russian military became more vulnerable to the anarchy provoked by the February Revolution of 1917. The demoralized Russian army disintegrated gradually, in result the officers were to support the Ukrainian Central Rada or to submit to the Temporary Government of Russia. Non-regular officers declared their support to democratic transformations in Ukrainian lands while regular ones were dissatisfied with the new order in the army and did not want to experience a decline in their social status. Therefore, they took the opposite position. As a result, pro-democracy officers won, declaring their unwavering intentions to build a regular army. There was a gradual transformation of the consciousness of officers and the transition from the paradigm of "officer-maloros" to "officer-Ukrainian". Despite the anti-militarist policy of the Central Committee, in general, the political views of officers and government officials coincided. The vision of most officers was the autonomy of Ukraine as part of the federal republic of the former Russian Empire.

Keywords: Ukrainian Revolution throughout 1917-1921, officer's corps, Central Rada, social and political attitudes, artillery. 